\title{
Employment Policy in the Times of Recession
}

Lech Keller-Krawczyk, PhD

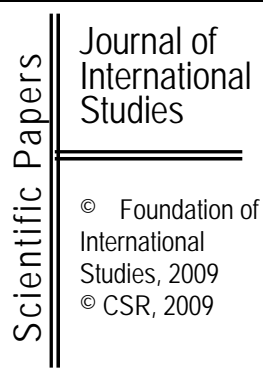

Academy of Humanities and Economics in Lódý,

Poland

\begin{abstract}
In this paper I analyse the (usually contractionary) employment policy in the recession times, analyse employment as a source of company's profits, dismiss the "greatest management lie", i.e. the empty declaration that "people are the greatest asset of the company" and try to find what are really the most important assets of the company. According to my research they are, as a rule: ehe brand and reputation of the company, fixed assets of the company, company's rights to natural resources, money owned by the company, patents, algorithms, secret recipes, systems and processes owned by the company and company's customer base.
\end{abstract}

Keywords: Employment policy, recession, assets, employment, employees, work force

JEL classification: E24, J21, P1, Q4

\section{Introduction}

Companies, especially in the West, frequently proclaim that "people are their greatest asset"1. Unfortunately, this claim is too often only an empty slogan rather than a real commitment made by the management. Not only employees know well, whether the management values them or not, for example by the way they are treated (and not by what they are told), but, what even is more important, in times of recession it is the people (workers, employees), who are dismissed, whilst machinery is usually kept, waiting for the better times.

\section{Recession of 2009}

For example, Microsoft announced recently, that in the forthcoming 18 months, 5 thousand of its employees would be dismissed, of which 1400 immediately, because of $11 \%$ drop in profits in the last three months of $2008^{2}$. The result should be a drop of operating costs

\footnotetext{
${ }^{1}$ For example: Terry Bragg "'Our people are our greatest asset': Lip service or reality?" on http://www.terrybragg.com/Article_OurGreatestResource.htm (22 January 2009).

2 "Microsoft zwalnia w trybie natychmiastowym 1,4 tys. osób. Akcje mocno w dół" Gazeta Wyborcza 22 January 2009.
} 
by 1.5 bln USD. The problem is that this American disease quickly spreads over the World, for example, according to Bloomberg ${ }^{3}$ :

Australian employers probably cut workers for a second month in December as slower domestic growth threatens to tip the economy into its first recession since 1991. Employment fell 20,000 after declining 15,600 in November, according to the median estimate of 17 economists surveyed by Bloomberg News. The jobless rate rose to 4.5 percent, the highest in almost two years, the survey predicts. The figures will be published tomorrow at 11:30 a.m. in Sydney. Rio Tinto Group and Australia \& New Zealand Banking Group Ltd. are among companies firing workers amid mounting evidence Australia will follow the U.S., Europe, U.K. and Japan into a recession.

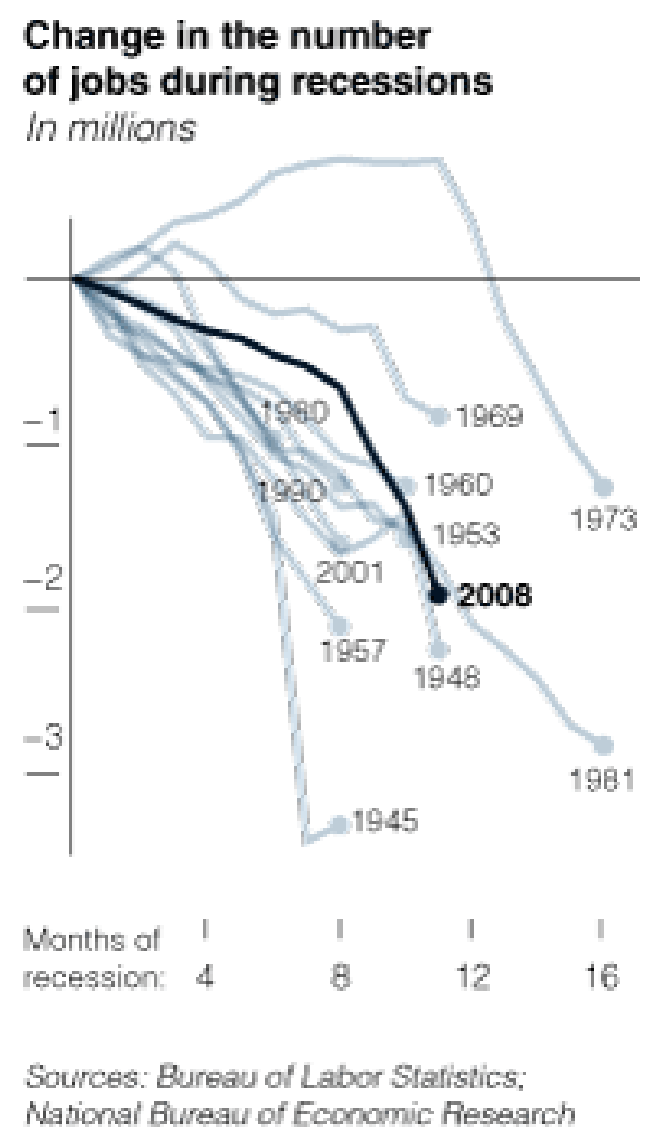

THE NEW YORK TIME:

Fig. 1 Change in the number of jobs during recessions in the US

Source: Louis Uchitelle, Edmund L. Andrews, Stephen Labaton "U.S. Loses 533,000 Jobs in Biggest Drop Since 1974” The New York Times (5 December 2008)

In North America, according to prestigious The New York Times4, U.S. alone lost in November 2008 over half a million jobs, which was the biggest drop there since 1974:

"We are caught in a downward spiral in which employment, incomes and spending

\footnotetext{
${ }^{3}$ Jacob Greber" Australian Employers Probably Cut Jobs as Recession Looms" on http://www.bloomberg.com/apps/news?pid=20601081\&sid=aeAXY30qY7lc\&refer=australia (23 January 2009). ${ }^{4}$ Louis Uchitelle, Edmund L. Andrews, Stephen Labaton "U.S. Loses 533,000 Jobs in Biggest Drop Since 1974" on http://www.nytimes.com/2008/12/06/business/economy/06jobs.html (5 December 2008).
} 
are collapsing together," said Nigel Gault, chief domestic economist for IHS Global Insight. "With private spending frozen, we have no choice but to rely on a stimulus package to revive the economy." The unemployment rate rose to 6.7 percent, up just twotenths of a percentage point from October, but up six-tenths over the last three months. More than 420,000 men and women who had been working or seeking work in October left the labour force in November.

More significantly, the unemployment rate does not include those too discouraged to look for work any longer or those working fewer hours than they would like. Add those people to the roster of the unemployed, and the rate hit a record 12.5 percent in November, up 1.5 percentage points since September. Noting that 1.9 million jobs have been lost since the start of the recession a year ago — two-thirds of them since September (...).

\section{Employment as a source of profits}

Reading this, and similar texts, one can have an impression that employees are nothing more than a burden, that can and should be shed during the hard times. One also can ask a question: what is then the rationale of employing people, if they generate costs? Obviously, a capitalist firm employs people only if the value of goods or services produces by them is higher than the cost of their employment (which can be reduced to salaries and wages, for the better clarity). In other way: a firm employs an employee only when that person, by his or her work, generates a profit for the firm's owner(s). When there is a recession, i.e. drop in the aggregate demand, then sales are also down, so companies initially decide to reduce the level of employment, as people are much more flexible than machinery.

Imagine a specialised company producing, say, pins (as in Adam Smith's Wealth of Nations $^{5}$ ). Such a company possesses machines that convert wire into pins, and that machinery is serviced by people. Let us assume that one production line makes, say a million pins a year, and employs ten persons. During the good times, this factory runs 10 such lines, employs 100 workers and makes 10 million pins. However, during the recession, when demand drops to, say 50\%, it stops 5 lines and dismisses 50 workers. Nevertheless, those 5 dormant production lines are usually stored, awaiting better times, why 50 people becomes instantly unemployed.

This is the "curse" of workers, as they are much more flexible than machines: a production line designed to make pins can only produce pins, while the same worker can be employed in different factories, producing different goods. However, employees are mistreated not only during the recession. Even more: not only do the companies (too) frequently mistreat their employees, but they also act like if their employees were idiots that could be easily fooled with false claims. Nevertheless, management of those companies forget, that their employees are no idiots (anyway: who would employ an idiot in a privatelyowned firm in the free market economy?), so that managerial rhetoric, as a rule, fools no one, but only the managers who use it.

Terry Bragg ${ }^{6}$ gives an example of a growing American company whose new CEO sent a letter to each employee, in which he declared that 'employees were the greatest asset of the company and that the company highly valued its employees'. This looked like a great rhetoric and a good personal touch, but, unfortunately for the CEO, that letter did not fool anyone into

\footnotetext{
5 (1776) - http://www.adamsmith.org/smith/won-intro.htm ((20 April 2009).

6 “'Our people are our greatest asset': Lip service or reality?" op. cit.
} 
believing they were really well treated by the management, as this company has an obvious 'glass ceiling' preventing women from advancing their careers. The company's management was a "good old boy's club", discriminating against women and ethnic minorities. As women and minorities were not part of the senior management team, so the increasing diversity in the workplace possessed a serious threat to senior managers in the company. Although they made claims about valuing people, the management was not recruiting or encouraging women and minorities to advance within the company, as they were simply not welcome in the traditional 'good old boys' network.

\section{Managing the work force during the recession}

According Terry Bragg ${ }^{7}$, the following tips should help to show the employees that they are truly valued by the management, especially during the hard times:

1. Do not downsize. According to Bragg and other management "gurus", downsizing clearly contradicts claims that people are valuable for the firm. If downsizing is really necessary, then cut should be applied to the people at the top, who mismanaged the company (for example by not preparing for the incoming recession). According to Bragg, "the CEO is probably a good place to start. Giving senior managers hefty bonuses after laying off lower level employees sends a mixed message and confuses people about whom the company really values. If you value people, then find the ways to keep them".

2. Invest in training. According to Bragg, the best way to invest in employees is to train them to keep their job skills current and marketable. Although companies frequently evade training because they are afraid the employees will take the training and then leave, the real question is, "what will you do if you don't train them, and they stay?", as both the company and its employees benefit from training, so it is usually a small cost for the benefit the firm can gain by training their work force.

3. Share the wealth. Rewarding employees by sharing the financial success of the company sends them a clear signal that they are treated as financial partners by sharing profits or receiving bonuses based upon the financial performance of the company. It is important to not just reward the top managers - the rewards should be "pushed down": to the front line workers.

4. Treat people with respect. This shows that the management trusts them and values their contributions. Employees should be allowed to make decisions that affect their work and have a right to privacy. It is not enough to just pay a lip service to their empowerment.

5. Create a place where people want to work. This is, according to Bragg, the 'Field of Dreams' approach, and "if you make it, they will come". A good workplace is a place where people want to work and thus the management will not have to worry about recruiting good employees, as "your satisfied employees are your best recruiters". The company will not have recruitment problems if it has satisfied employees who tell their friends and relatives how much they enjoy their jobs and like the company for which they work.

Therefore, according to Bragg the way to success is to "show your employees that they are your greatest asset by treating them as partners. Your actions always speak louder

\footnotetext{
7 Ibidem.
} 
than your words. Your empty words will not fool people you have mistreated. If employees are fleeing your company, you know you have a problem that words alone won't fix" ${ }^{\prime \prime}$.

\section{The Biggest Management Lie: 'Our People Are Our Greatest Asset'}

According to the Progressive Managers' Network" ${ }^{9}$, "It is rare to work in an organisation these days that does not claim that 'Our people are our greatest asset"'. This is obviously a big lie, as the truth is that some people are assets, while others are liabilities, and managers find it usually hard to tell the difference, as managers who can effectively work with both assets and liabilities are extremely rare. So if people are not the greatest asset of a firm - then the question is: what are those most important assets? According to the Progressive Managers' Network, ${ }^{10}$ they are as in table below:

Table 1 Most important assets of a company (firm) according to the Progressive Managers' Network

\begin{tabular}{|c|}
\hline Assets: \\
\hline Ideas \\
\hline Passion \\
\hline Energy \\
\hline Commitment \\
\hline Skills \\
\hline Time \\
\hline
\end{tabular}

Source: http://progmanager.wordpress.com/2007/11/16/our-people-are-our-greatest-asset-thebig-lie/ (23 January 2009).

The rationale behind this list is emerging from question: "how would we manage people to harness every idea, every ounce of passion, energy and commitment, and every skill; to make sure that none is wasted?" And then, focusing on what we expect people to contribute to our organisation, holds the key to significantly improving our effectiveness as a manager" 11 .

Donald Taylor ${ }^{12}$ presents similar list, only better developed. According to him, the most important assets of a company (firm) areas in table below:

\footnotetext{
8 Ibidem.

9 http://progmanager.wordpress.com/2007/11/16/our-people-are-our-greatest-asset-the-big-lie/ (23 January 2009).

10 Ibidem.

11 Ibidem.

${ }^{12}$ http://donaldhtaylor.wordpress.com/2007/03/20/people-are-our-greatest-asset- $\%$ E2\%80\%93-you-justcan $\%$ E2\%80\%99t-say-it/ (23 January 2009).
} 
Table 2 Most important assets of a company (firm) according to D. Taylor

\begin{tabular}{|l|l|}
\hline Asset & Examples of companies \\
\hline The brand and/or reputation & Nike, Gucci, etc. \\
\hline Fixed assets & Property developers, landlords \\
\hline Rights to natural resources & Mining and oil companies \\
\hline Money & Banks, insurance companies etc. \\
\hline Algorithms & Google, Microsoft \\
\hline Secret recipes & KFC, Coke, Pepsi \\
\hline Systems and processes & Widespread \\
\hline Customer base and membership & MySpace, clubs etc. \\
\hline Patents & Pharmaceutical companies \\
\hline
\end{tabular}

Source: Donal H. Taylor "People are our greatest asset - you just can't say it" on http://donaldhtaylor.wordpress.com/2007/03/20/people-are-our-greatest-asset-0E2\%80\%93you-just-can $\%$ E2\%80\%99t-say-it/ (23 January 2009)

Finally, according to Bill Fiduccia ${ }^{13}$, the most important assets of a company, that should be protected in the first place are:

Patents, copyrights and trademarks, as they document company's ownership and create certain legal protections to help protect company's property. In order to receive a patent or trademark, one must submit an application to the appropriate governmental agency explaining why the asset is proprietary to that person (physical or legal). Even though ownership of copyrights is possible filing for it, one should file to fully protect those rights, and have a lawyer to assist with these applications.

Confidentiality or nondisclosure agreement, as these documents commit a party to keeping specified data and information confidential and out of the hands of unintended parties. They are designed to protect company's valuable trade secrets. These agreements can be very simple or very detailed, depending on the requirement, so one should always consult a lawyer on this.

Employment agreements, as these agreements stipulate that all company assets are proprietary and that unauthorized disclosure of confidential information such as pricing formulas, customer lists and other important data and information is legally prohibited. In addition, these agreements help ensure that any invention or discovery made by an employee while

13 Bill Fiduccia "Protecting Your Company's Most Important Assets" in Entrepreneur November 2001 on http://www.entrepreneur.com/magazine/entrepreneursstartupsmagazine/2001/november/45740.html (20 April 2009). 
employed with the company is the property of the company (at least in some countries, such as the US).

Computer passwords, safes and locked file cabinets that can restrict access to proprietary information, but only if the company uses them.

Data backup, as company should be backing up everything, that is important. Digital documents should be backed up on a server that is in a different location, along with copies of important physical (paper) documents.

The rationale, according to Entrepreneur is that "theft of your most valuable assets or loss of assets due a calamity can ruin an emerging business. When you leave your home in the morning, you lock your front door to protect your personal property. Why not do the same for your company's most valuable business property?", but employees are missing from that list of most valuable assets of the company...

It is also interesting that Donald Taylor ${ }^{14}$ ends his elaborations by saying "we value our people. Our value comes from them". This is a truly Marxist statement, but strangely coming from a British management "guru". It is strange, as according to Karl Marx the profit comes from the human work - in his labour theory of value he made claims (after Adam Smith and David Ricardo) that the values of commodities are related to the labour needed to produce them ${ }^{15}$. Although this theory has many influential enemies ${ }^{16}$, it well explains the mechanism of the free market capitalism, especially the business cycles producing recessions similar to the current one, and exceptionally well explains why individual capitalist act against the fundamental interests of their class, and this way they deepen the recession by dismissing their work force, seen by them as an unnecessary burden, and not as a source of demand, that keeps the free market capitalism going.

\section{Conclusion}

It looks like no one was again prepared for the recession, that had to come after the period of relative prosperity, and that virtually every capitalist firm tried hard to avoid thinking about hard times, that are inevitable in free market capitalism. It is the recession time, when corporate employment policies are really tested, and it is sad to say, that as in the past, virtually every firm failed that test miserably.

\section{References}

1. Terry Bragg "'Our people are our greatest asset': Lip service or reality?" on http://www.terrybragg.com/Article_OurGreatestResource.htm (22 January 2009)

2. Bill Fiduccia "Protecting Your Company's Most Important Assets" in Entrepreneur November 2001 on http://www.entrepreneur.com/magazine/entrepreneursstartupsmagazine/2001/novemb er/45740.html (20 April 2009)

\footnotetext{
${ }^{14}$ Op. cit.

${ }^{15}$ http://en.wikipedia.org/wiki/Labor theory_of_value (23 January 2009) and http://www.worldsocialism.org/articles/introduction_to marxian_economics1.php (23 January 2009).

${ }^{16}$ For example the so-called International Society for Individual Liberty http://www.isil.org/resources/lit/labortheory-val.html (23 January 2009).
} 
3. Gazeta Wyborcza "Microsoft zwalnia w trybie natychmiastowym 1,4 tys. osób. Akcje mocno w dół" Gazeta Wyborcza 22 January 2009

4. Jacob Greber" Australian Employers Probably Cut Jobs as Recession Looms" on http://www.bloomberg.com/apps/news?pid=20601081\&sid=aeAXY30qY7lc\&refer $=\mathrm{a}$ ustralia (23 January 2009)

5. Margareta Holmstedt Employment Policy London: Routledge, 1991 (Spicers European Policy Reports)

6. International Society for Individual Liberty "Labour Theory of Value" http://www.isil.org/resources/lit/labor-theory-val.html (23 January 2009)

7. Harry Landreth i David C. Colander Historia Myśli Ekonomicznej Warszawa: PWN, 2005

8. Ernest Mandel An Introduction to Marxist Economic Theory New York: Pathfinder Press, 1979

9. Donal H. Taylor "People are our greatest asset - you just can't say it" on http://donaldhtaylor.wordpress.com/2007/03/20/people-are-our-greatest-asset$\%$ E2\%80\%93-you-just-can\%E2\%80\%99t-say-it/ (23 January 2009)

10. Silvana Sciarra, Paul Davies and Mark Freedland (editors) Employment Policy and the Regulation of Part-time Work in the European Union - A Comparative Analysis Cambridge: Cambridge University Press, 2004

11. Adam Smith An Inquiry into the Nature and Causes of the Wealth Of Nations Edinburgh: 1776 on http://www.adamsmith.org/smith/won-intro.htm (20 April 2009)

12. Louis Uchitelle, Edmund L. Andrews, Stephen Labaton "U.S. Loses 533,000 Jobs in Biggest Drop Since 1974" The New York Times of 5 December 2008

13. Wikipedia "Labour Theory of Value" on http://en.wikipedia.org/wiki/ Labor theory of value (23 January 2009)

14. World Socialist Movement "An introduction to Marxian economics 1: the labour theory of value" on http://www.worldsocialism.org/articles/ introduction to marxian_economics1.php (23 January 2009). 